\title{
Towards Formulating Urban Cultural Heritage Conservation Strategies in the Former Tin Mining Towns in Lembah Kinta, Perak
}

\author{
Mohd Rifzal b Mohd Shariff *1, Esmawee Hj Endut ${ }^{1}$, Ahmad Faisal Alias ${ }^{1}$, and \\ Nor Haslina Bt Jaafar ${ }^{2}$ \\ ${ }^{* 1}$ Faculty of Architecture, Planning and Surveying, \\ Universiti Teknologi MARA \\ ${ }^{2}$ Architecture Department, \\ Faculty of Engineering and Built Environment \\ Universiti Kebangsaan Malaysia. \\ Corresponding author: rifzal@iium.edu.my
}

\begin{abstract}
The existence of old former tin mining towns are invaluable asset in the country for people to understand the cultural and historical essence of a place and its people.The formation of former tin mining towns in Malaysia related closely to the development of economy activities which shows the mix cultural development between races, invention of buildings, transportation routes and accessibility which developed the early tin mining industry, port city and work as a state administrative centre. However, the conservation efforts in most of these towns were neglected due to rapid urbanization, uncontrolled urban encroachment which jeoperdized the old towns whilst the social structure and urban distinctiveness become dilapidated. Therefore, this paper focuses on how the conservation of ex-tin mining town in Malaysia which could contribute to safekeeping Malaysian cultural heritage entities in order to regenerate cultural heritage entity especially in Perak. Pekan Papan, Perak has been chosen as a Case Study due to its distinctive characteristics as an early tin mining town and its historical significance of Malaysia's economy activities and attribution to mix cultural heritage. The qualitative method based on Case study, observation and non-structured interview were used to explore, identify and evaluate the tangible elements in the selective extin mining old towns as a cultural heritage resources by reviewing the definitions and concept of physical characters and cultural value which contribute to the identity of a place. The analysis of the research are based on thematic analysis which based of the old town's physical characteristic comprised of urban structure and Architectural features and its interrelationship with distinctive local culture activities which created an awareness on the cultural heritage value and determined the formulation of an urban cultural heritage strategies for the former tin mining towns in Malaysia.
\end{abstract}

Keywords: Cutural Heritage, Former Tin Mining Towns, Physical Character, Conservation

\section{Introduction}

The formation of the tin mining towns in Perak could be reviewed from the early history since1848, where tin was discovered in Larut district, Perak which formed towns such as Taiping and Larut Matang. The first tin rush happened 1861 where tremendous rise of the international price of tin which derive Chinese immigrants to open a smaller tin mine in uncultivated land or borrowed indigenous Malay Land in Kinta District (Esmawee Haji Endut, 1995). As a result, new tin mining towns were opened between 1877 and 1880s under 
the rules of Malay Sultanate. In 1882, tin rush were dominated by the 'European Company' which formed Tin Mining Company and raised towns such as Tambun, Ampang Tanjung Rambutan, Menglembu, Chemor, Kampar and Tanjong Tualang as mining centers. However, the decline of tin mining operation have linked to the collapse of world tin market in 1985 which led to the abandonment of mine sites and its township in Perak. Old Towns such as, Gopeng, Papan, Temoh, Lahat, Tambun, Ampang, Tanjung Rambutan, Menglembu, Chemor, Kampar, Chenderiang, Tanjung Tualang, Pusing, Kota Bharu and Siputeh. Many research have been made in identifying heritage sites as an entity of cultural heritage tourism area, however the ignorance of the former tin mining towns in Lembah Kinta which have heritage and historical were amongst the factor which derived to its abandonment and deterioration.

The UNESCO (1972) convention on world heritage defined cultural heritage as it is the combination for material manifestations, living expression, and as well as the traditions of the communities. According to Kovathanakul (2006), she defined cultural heritage as an inheritance from the past which contains events, places, and people. In the similar vein, Lertcharnrit (2008) has provided another version of definition for cultural heritage, and it is explainable in a way that these products are range from antiquities, artwork, monuments, sites, heritage buildings, and historical urban areas with the characteristic of intrinsic values (Sarttatat, 2010).

This research aimed at exploring the potential of conserving former tin mining towns which have distinctive characteristic and historical value in Malaysia as a multi-cultural heritage resources. The main objective of this paper is to explore the significant and distinctive characteristics of former tin mining towns in Perak which worth to be conserved from the view of tangible elements .The findings on the tangible elements in the townscape will be categorized from the identification of the distinctive elements of the physical characteristic in the old towns comprising of the urban structure and architectural features. The exploration of the old town's morphology from the physical characteristic and its relationship to local culture activities will determine the potential cultural heritage value towards urban conservation strategies and to regenerate cultural heritage tourism.

\section{Problem Statement}

\section{Abandonment of Cultural Heritage Resources}

The definition of Cultural Heritage means experiencing the places and activities that authentically represent the stories and people of the past and present (Chourasia \& Chourasia, 2014). Most of the former tin mining towns in Perak have distinctive historical value which contributes to its cultural heritage essence. This could be seen from the tangible elements especially from its existing built forms which rich with architectural features and cultural activities. In current conditions most of the built forms in these towns were left abandoned and dilapidated especially on the simple building condition that do not stand as landmark or structural significant in urban definition. Therefore the contribution of these old towns to urban coherence and socio cultural are poorly understood which caused the ignorance, abandonment and replaced by the rapid development.

\section{Conservation Action of the Former Tin Mining Town in Perak}

In Perak, there are many evidence of heritage urban forms which still exist, conserved and promoted as a tourist attraction for the purpose of cultural heritage tourism product. One of the attraction are sites which relate to tin mining activities and have distinctive characteristics and historical significant in the state of Perak. For example, Tanjung Tualang Tin Dredge no 5 
(TT5) is the only one which still exist and have been conserved as heritage entity as one of the tourist attraction in Perak. The development of tin mining industry also related to the formation of the tin mining towns in Perak. According to Khoo and Lubis (2005), some 15 mining towns in Kinta that evolved during 'tin rush' and its expansion era back in 1880's until 1900s. In current conditions, the existing ex-tin mining towns in Perak are still exist, some were still vacant, conserved, adaptively re-used but many of it were left in abandonment and in dilapidated condition due to the closure of tin mining activities, railway station or due to new development of infrastructure such as new township or roads. The state of Perak has promoted various heritage and historical place as Perak's tourism package.

Table 1 The Current Condition of Former Tin Mining Towns in Lembah Kinta, Perak Conserved/existing operational/ Exist but in abandonment and Totally Demolished and replaced some were abandoned.

\begin{tabular}{lll}
\hline Batu Gajah & Papan & Tambun \\
\hline Gopeng & Kota Baharu & Ampang \\
\hline Kampar & Lahat & Tanjung Rambutan \\
\hline Chemor & Kepayang & \\
\hline Menglembu & Siputeh & \\
\hline
\end{tabular}

Pusing

Tronoh

Source: Authors

\section{The Lack of Understanding on The Town's Physical Characteristic as Source of Cultural Heritage Resources}

Most of the formation of the former tin mining towns have contributed to the enrichment of its cultural heritage value from distinctive history and the character of its townscape and architectural features. These towns were opened during colonial period for the purpose of tin mining activities. Historically the development of the towns involved multiracial involvement where Malay Sultanate act as the owner, while Chinese as the main worker and The British Colonial as the main tin importer. The value of these former tin mining towns have established as distinctive cultural heritage resources that were a mixture of various architectural styles modified to the Malaysian environment. However in present, due to rapid development and the conditions of the buildings, most of the ex-tin mining towns in Perak were left abandon or demolished for the future development. The awareness towards conservation include areas with attractive character and strong sense of identity which must be maintained and enhanced and, where practicable, other areas are upgraded to provide an improved sense of identity and place which include historical and heritage buildings. Orbasli (2002) denotes that urban heritage exist as the physical attributes of building forms, public spaces and urban morphology that experienced by the progenies in present day and creating the heritage for future generations.
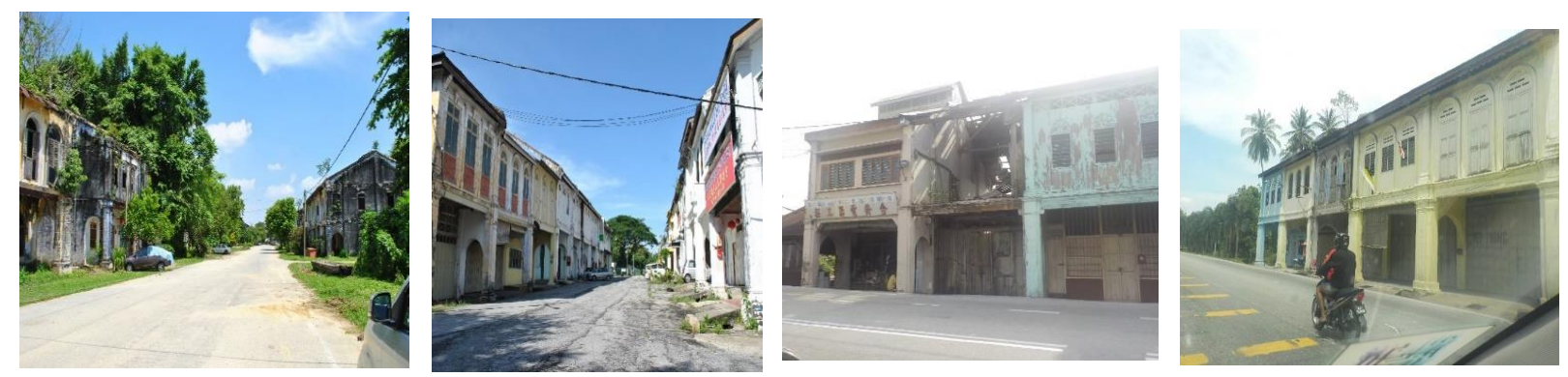

2.Papan
3. Lahat
4. Temoh
5. Kepayang

Figure 1 The Ex-Tin Mining Towns in Lembah Kinta Such as Papan, Lahat, Temoh, Kepayang and Siputeh Which Still Exist but Yet to Be Abandoned and Left in Dilapidated Condition

Source: Authors

\section{Study Area}

Pekan Papan was chosen as the study area of this research due to its entity as the first center for tin mining in Kinta Valley. It is located next to Batu Gajah and Pusing and once the most developed tin mining town in Perak during British Colonial period. The town consists of varieties of built forms such as houses, school, houses of worships, public buildings, entertainment premises and recreational areas as a result of multi-cultural development. This could be seen from the existing built forms such as shop houses and town houses which were vacated by the Chinese and influenced with Malaysian Chinese and Colonial Architecture. The traditional Malay Architecture could be seen from the essence of Malay community area such as Istana Bilah, mosque and Malay house. These buildings were combined together to form Pekan Papan as a mix culture town and as part of Malaysian architectural identity.

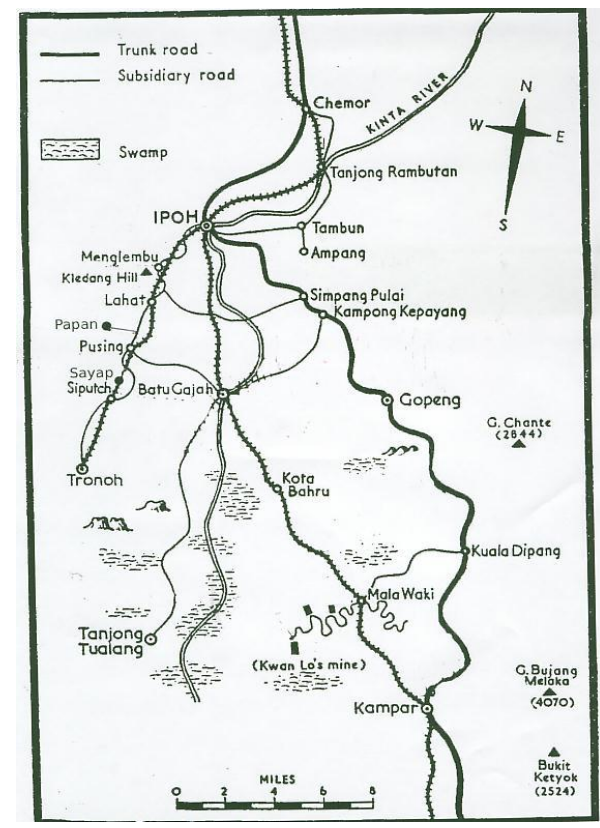

Figure 2 The Historical Map of Tin Mining Towns in $18^{\text {th }}$ Century Shows Location of Papan and Other Tin Mining Towns Through Roads and Railway Tracks and Towns in Lembah Kinta, Perak

Source: Perak Heritage Society

\section{The Historical and Cultural Significant of Pekan Papan}

The settlement of Papan started as a timber town in the 1840s. Papan's history is enriched with the legacies of historical figures and as an evidence of the mix culture population in the development of the earliest town in Malaysia. There were the Mendailing nobilities, Raja Bilah and with the sole right awarded by the British to open tin mine and became the richest tin-mines in the Malay Peninsula. 
Another legacy of Papan historical significance were Dr A. C Kathiagasu and his wife Sybil, a prominent obstetrician. During World War 2, they have provided medical services to the freedom fighters of the Malayan People's Anti-Japanese Army (MPAJA) and force 136 operatives who hid in the hill nearby. After twenty months, their service have been discovered by the Japanese and they were arrested, tortured and jailed. For their heroism, both Sybil and Dr Kathiagasu were honored after the war. The clinic which opened along shophouses in Papan remains as monument to their courage.

Papan today is a small vibrant town of people who work as shopkeepers, farmers, chitblind makers and a few tin-miners. In the past thirty years, as the population declined, buildings were neglected. They fell into ruin or were destroyed for building materials. However, some of its heritage has survived. A village of devoted local people still continue to live in buildings which were left abandon and in dilapidated conditions. Due to rapid development and the conditions of the buildings, these buildings might be left or demolished for the future development.

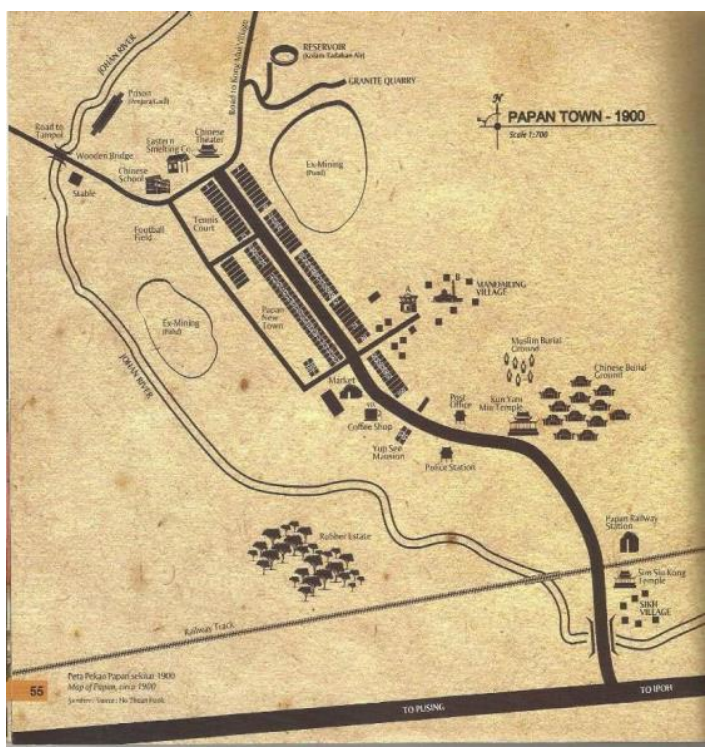

4. Papan in 1900

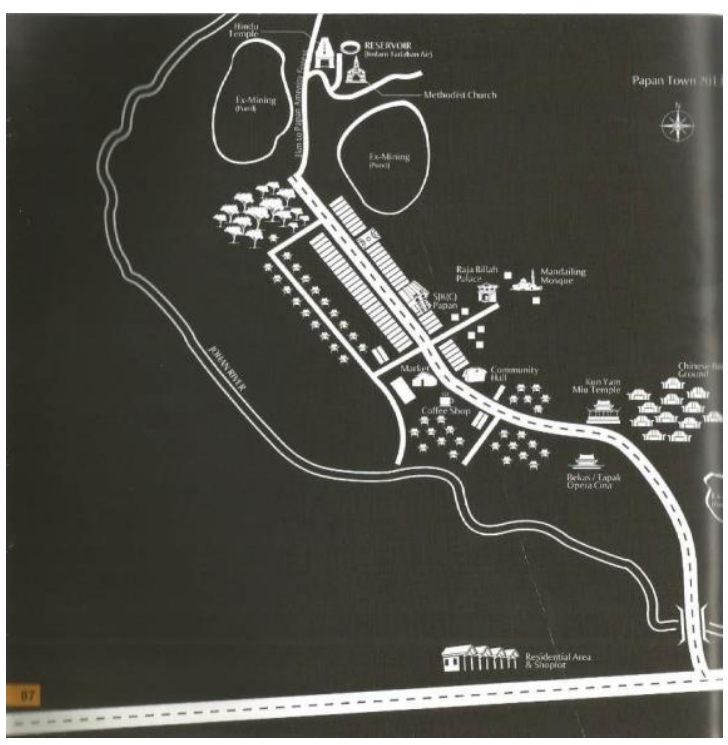

5. Papan in 2011

Figure 4 \& 5 Plan of Pekan Papan in 1900 and 2011 Shows the Layout of Buildings Consists of Variety Built Forms Influenced by Mix Culture Development. Some Landmarks That Noted Papan As A Developed Towns Such as Prison and Horse Stable Have Been Demolished

Source: Ho Thean Fok

\section{Methods}

The study are focusing on the physical characteristics of the towns which consist of the tangible quality in the former tin mining town. The aim of the research is to create strategies for the purpose of urban conservation and to regenerate the interpretation of cultural heritage value. The qualitative method will be used which mainly based on primary and secondary data The primary data will be collected focusing on case study of selective towns by using in depth investigation and observation towards a specific phenomenon setting of the urban 
structure and architectural features, development process and relationship to the local cultural activities while the secondary data will be collected from others include reports, journal, articles and book.

There are many researches related to physical characteristic related to urban design and architectural features. The analysis of this research will be based on thematic analysis with reference to the observation and cognitive mapping of the design approaches based on 5 Lynch (1960) elements: (Path, nodes, district, edges, landmarks). The results are related to urban forms and activities which attributes on the tangible elements, focusing on physical characters and qualities based on the distinctiveness and recognisable elements. through urban structure and the architectural features. The recognizable physical qualities are identified as familiarity; historical significant; nostalgic memory; affinity; special quality of a place; dislikes; and association. The meaning and association experiential qualities will be measured by the vista; the human scale; the activity on the ground level; the mixture of activities; the historical significance; the quality of view from aesthetic appreciation of kinaesthetic experience. All this qualities are the factor which contribute to the formulation of urban conservation strategies of the former tin mining towns in Lembah Kinta.

\section{Findings and Argument}

\section{Formulation of Cultural Heritage Conservation Strategies of Former Tin Mining Towns in Lembah Kinta, Perak From the Identification and Analysis of Physical Characteristic}

In order to achieve the conservation strategies and action through the interpretation of cultural heritage, the recognition of the physical characteristic of the place itself is the most important factor to be considered. As in describing the identity of the place, the presence of distinct elements must be recognised and remembered by people (Shuhana, 2011). Human activity is the second component of the identity of the place. Physical environment provides the setting for the activity to take place. Thus this leads to how people response physically and mentally in term their behaviour pattern towards the tangible elements which is the built forms and the intangible elements from activities within the area.

In this study, the identification of physical qualities are obtained from the aspects of urban structure and architectural features. The variety of users within the community of the old town will foster the sense of belonging or place attachment of the area. The existing old significant buildings such as the shop houses, the palace and civic buildings that have distinctive and recognizable character need to be retained and conserved as the local community has memory and association with them.

From the perspective of urban quality, increasing the permeability, legibility and robustness of the physical setting will eventually support the town's activities. A better physical setting is needed to add robustness and richness to the place as it will support the variety of activities for social interaction day and night. The legibility of the streets along the built forms needs to increase by having a distinctive character as it contributes to help people to recognise and remember the areas within the place. The hierarchy of the street layout also need to be be improved by having the distinctive unifying character of streetscapes. The unique "kaki-lima" elements are one of the recommendations as unifying elements for the shop houses. The networking of side lanes and back lanes is identified as an alternative place of activities on ground level as increasing the permeability within the place. The legibility of the old towns will be influenced by the solid and void.

The architectural features especially at building facade within the built forms helps in creating visual appropriateness and distinctive character in creating the town identity. The 
differences of building frontage will create variety and redefined the grain. The roofscape, façade treatment and material usage of the existing buildings can be analyzed to identify the harmonic visual experiences by recognizing the sense of rhythm and pattern. The sensitivity to the harmonic relationship which concerns the relationship between the parts and how the material fit together to form a coherent whole that can create a strong identity of places.

The visual orientation also can be used in achieving a visual balance of the elements within the buildings. Colours are one of the syntheses of unifying elements that increase the distinctive visual identity. Unity within variety needs to be addressed in identifying the sameness in character. The effect of visual experience of place recognition is very important for identification of an area. A visual stop will be identify within the townscape area by promoting vista on architectural detailing.

The selected building will be the visual stop for cultural, place of worship and community function and these building carry meaning and association to the place. The sense of enclosure of built forms needs to be identify as to enhance the spatial volume which can determine the quality of perspective view of the area. Distinctive streetscapes elements will enhance the deflection effect and increase the imageability of the street.

\section{The Cultural Heritage Qualities in Pekan Papan}

The main criteria that determined the cultural heritage quality in Papan is how the activity occurs within the physical setting. The unique character of the urban structure such as Street Square and back lane can be enhanced by introducing a high degree of sensory experience and the transparency of the activities. The physical setting for the temporal activities also must be able to support as in result will increase vitality and add vibrant to the built forms within the old towns.

The familiarity of people's perception at Papan is the activities along the street pattern of the shop houses and towards Malay population near Istana raja Billah. The old buildings and its surrounding place act as a frequent sighting of physical elements and carry along the historical significance. As the familiarity with physical elements in the area is closely related to the historical significance of the surrounding building within the built forms is considered distinctive, and places become recognisable.

The distinctiveness of urban pattern and the activities could be increased with the architectural features of old buildings where these buildings are a reminder of old and/ past time even though not because of its physical characters just of their presence will evoke the nostalgic memories, as people tend to have an affinity towards those place due to their special role in the past lives. As meaning is evoked by the physical form, the visual simulation in experiencing the place needs to be highlighted in the conservation recommendation. The creation of vista and emphasising on visual stimulation and appreciation will increase the visual memory of the place. The visual continuity of the activities between buildings and spaces will increase the sensory experience.

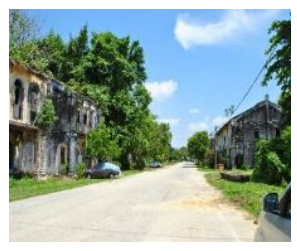

6

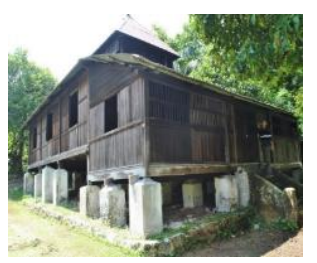

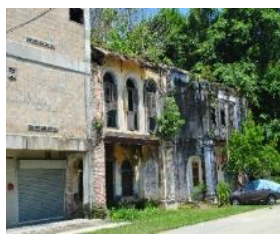

7

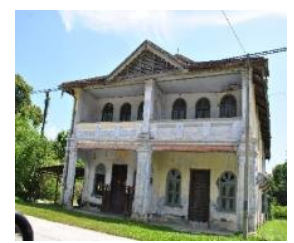

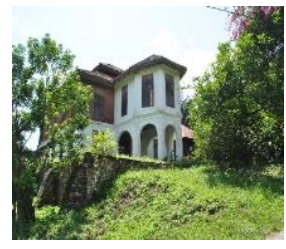

8

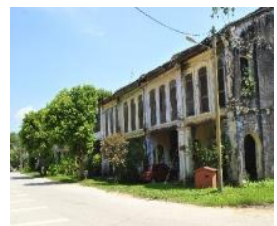


9

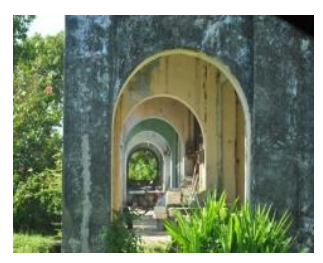

12

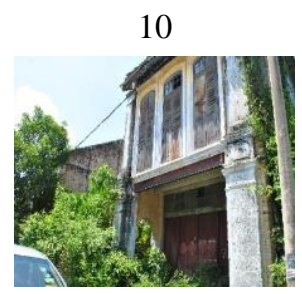

13

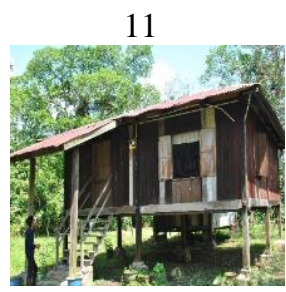

14

Figure 6-14 Physical Character of Papan- The Urban Structure of Pekan Papan- Street Pattern, Built Forms and Five Foot Ways. The Building Typologies in Papan Shows the Influenced of Mix Culture Development: Town Houses, Shophouses and Villa Which İnfluenced by Chinese and Colonial Architecture) while the Malay Traditional Built Forms Could Be Seen at Building Types Such As Mosque, House Amd Istana Raja Bilah.

Source: Authors

\section{Conclusions}

This study is significant as a record and documentation of existing former tin mining towns which have been abandoned as an essence of nation cultural heritage resources. In order to create the awareness, the action through the process of urban conservation are important as strategies to regenerate the former tin mining towns as cultural heritage resources.

In present condition these towns are in abandonment in dilapidated condition and might be demolished due to development. Distinctive physical characteristics of the former tin mining towns such as Papan should be understand by the stakeholders as an embodiment of economy and the close social culture in Malaysia. In current condition this street towns remains an interesting small town steeped in history and heritage of the days gone by. The unique of the old town's physical character with its richness of urban and architecture design, related to historical and cultural heritage as resources should be understand by future generations and stakeholders through the awareness from the process of conservation and could contribute as a guidelines for other abandon towns and various sector such as tourism and education.

\section{References}

Chourasia, B. \& Chourasia, A. (2014). Prospects of heritage tourism management in Bokaro of Jharkhand. VSRD International Journal of Business and Management Research, 2(10), 527-531.

Esmawee Haji Endut. (1995). The Architecture of Malaysia Transforming traditions. Asean Studies Publication Series

Khoo, S. N. \& Lubis, A. R. (2005). Kinta valley: pioneering Malaysia's modern development. Ipoh, Malaysia: Perak Academy.

Kovathanakul, D. (2006). The comparative of cultural heritage management of nan city and luang prabang: sustainable tourism perspective. Paper Presented at Proceeding of International Conference on Sustainable Local Heritage Conservation: the Tran disciplinary approach and ICOMOS Thailand Annual Meeting 2006, Udon Thani 
Province on November 17-18, 2006 (pp.273-271). Bangkok Thailand: ICOMOS Thailand.

Lertcharnrit, T. (2008). Cultural resource management. Journal of Thai Culture, 47(special issues), 31-34.

Lynch, K. (1960). The image of the city. Mass: MIT Press.

Orbasli, A. (2002). Tourism in historic towns: urban conservation and heritage management. New York: E \& FN Spon.

Sarttatat, I. (2010). Conservation and sustainable tourism in Sap Cham Pa Archaeological Site and Cham Pi Sirindhorn Forest. Unpublished PhD thesis, Silpakorn University, Thailand.

Shuhana, S. (2011). Townscape revisited: unravelling the character of the historic townscape in Malaysia. Johor Darul Ta'zim: Penerbitan UTM Press.

United Nations Educational Scientific and Cultural Organizations (UNESCO). (1972). Convention concerning in protection of the world cultural and natural heritage. Retrieved from http://whc.unesco.org/archieve/convention-en.pdf 